\title{
The Reasonable Person for Our Time for Reasonableness in a Heterogeneous Society
}

\author{
Ceilia Divakaran* \\ Charles Darwin University School of Law, Darwin, Australia
}

\begin{abstract}
The cases of Bugmy and Munda decided by the High Court of Australia in 2013 raised the impact of social deprivation on Aboriginal defendants, in that it mars the development of an individual exposed to alcohol and alcohol-fuelled violence, and that full weight must be given to this in sentencing considerations. This significant legal precedent, in the backdrop of Aboriginal over-representation in the criminal justice system, invites the question of the relevance of the characterisation of the reasonable person in the law of provocation and delivery of equal justice, in a culturally heterogeneous society such as Australia. The paper prosecutes the case for exploring the construction of a contemporary reasonable person clothed in Aboriginal identity, for equitable sentencing outcomes for Aboriginal defendants.
\end{abstract}

Keywords: Contemporising Reasonable Person, Equal Justice for Aboriginal Defendant, Reasonable Person Test in Heterogeneous Society.

How to Cite: Divakaran, Ceilia. 2017. "The Reasonable Person For Our Time For Reasonableness In A Heterogeneous Society”. Udayana Journal Of Law And Culture 1 (2): 71-97. doi:10.24843/ UJLC.2017.v01.i02.p01.

DOI: https://doi.org/10.24843/UJLC.2017.v01.i02.p01

Copyright $@ 2017$ UJLC. All right reserved

\section{Introduction}

The social blight of Aboriginal overrepresentation in the justice system in Australia continues to pose a legal and moral challenge. ${ }^{1}$ Some jurists, through their judgments and discourse, have examined systemic deprivation in the background of Aboriginal defendants and its impact on Aboriginal offending, as evidenced in the wide discretion applied when an Aboriginal defendant is before their court. ${ }^{2}$

* Correspondence: duende@bigpond.net.au

1 Stephen Rothman AM, The Impact of Bugmy and Munda on Sentencing Aboriginal and Other Offenders, Paper delivered at the Ngara Yura Committee Twilight Seminar on 25 February 2014. His Honour makes the case for consideration in sentencing of Aboriginal defendants' who suffer exclusion from society, discrimination and disempowerment in an application of equal justice.

2 See Bugmy $v$ The Queen [2013] HCA 37, Munda $v$ Western Australia [2013] HCA 38, R $v$ Ipeelee [2012] 1 SCR 433, R v Gladue [1999]1 SCR 688. 
In Bugmy $v$ The Queen ${ }^{3}$, the Hon Rothman $\mathrm{J}$ described the High Court as having confined to the dustbin of judicial history ${ }^{4}$ a growing body of opinion to restrict the principle that neither time nor prior offending diminished the applicability of the Fernando principles. ${ }^{5}$ Legal scholars have also raised doubt about the 'reasonable person' doctrine, whilst having served the law well, nonetheless in a culturally heterogeneous society becomes even more a legal fiction. ${ }^{6}$ As Lord Reid pointed out in Healthcare at Home Limited $v$ The Common Services Agency (Scotland), in recent times, additional passengers from the EU have boarded the Clapham omnibus'. ${ }^{7}$

Australia's inheritance of the British Westminster system of law and its robustness to serve a culturally diverse nation, whilst upholding the virtues of equality before the law, has come into question. ${ }^{8}$ Achieving equal justice involves how substantive law and the legal system embraces cultural diversity, although law reform is always fraught, so we must look to administrators within the criminal justice system who may have a direct and beneficial effect on this goal. ${ }^{9}$

This research article is an inquiry into the merits of giving consideration to contemporising the 'reasonable person', and examining reasonableness under the circumstances in sentencing Aboriginal offenders, to achieve the goal of dispensing equal justice in the Aristotelian sense of 'formal equality'. ${ }^{10}$ The research examined the meaning of equality and equal justice in the context of a multicultural society, with a focus on Aboriginality of defendants before the courts. The article discusses the challenges to the traditional construction of the 'reasonable person' test and the relevance of its characterisation in respect of an Aboriginal accused. A possible consequence of this is to expand the scope of individualised justice in sentencing to include Aboriginality as a mitigatory factor, so as to improve justice outcomes for Aboriginal defendants in the justice system. It is argued there may be a case to be established for similar treatment of other minorities in societies outside Australia where sentencing considerations could be informed by the contemporised 'reasonable person' test.

It is now 25 years since the Royal Commission into Aboriginal Deaths in Custody handed down its final report containing 333 recommendations to address Aboriginal

3 Bugmy $v$ The Queen [2013] HCA 37.

4 Rothman AM,loc.cit.

5 Ibid.

6 The reasonable person has been portrayed as the spokesman who represents after all no more than the anthropomorphic conception of justice, is and must be the court itself'- Lord Radcliffe in Davis Contractors Ltd v Fareham Urban District Council [1956] AC 696, 728, See Hall v. Brooklands Auto-Racing Club (1933) 1 KB 205 for a reference to the reasonable person as the man on the Clapham omnibus.

$7 \quad$ Healthcare at Home Limited $v$ The Common Services Agency (Scotland) [2014] WLR(D) 351.

8 Robert French AC, "Equal Justice and Cultural Diversity: The General Meets the Particular", http: / / www.hcourt.gov.au/assets/publications/speeches/current-justices/frenchcj/frenchcj14mar15.pdf.

9 Ibid.

10 Anton- Hermann Chroust and David L Osborn, "Aristotle's Conception of Justice," Notre Dame Law Review 17, No. 2 (1942): http://scholarship.law.nd.edu/ndlr/vol17/iss2/2 
over-representation in the criminal justice system in Australia. ${ }^{11}$ Since that time, institutional deaths have increased and Aboriginal people remain over-represented in the prison population, at a rate of 12 times that of the rest of the Australian population. ${ }^{12}$ In the Northern Territory, Aboriginal people make up 29\% of the general population and $80 \%$ of the prison population. ${ }^{13}$ The Chief Justice of the Supreme Court of South Australia, in referring to the 46\% Aboriginal youth detention, said it was not just a crisis for the Indigenous community, but a crisis for the whole community. ${ }^{14}$

In the intervening years there have been other important inquiries and reports ${ }^{15}$ highlighting the social position of Aboriginal people in Australian society and their significant disadvantage. This body of knowledge has informed judicial thinking, giving rise to a growing number of cases ${ }^{16}$ where courts have handed down judgment distinguishing it on the basis of disadvantage suffered by the Aboriginal defendant. The High Court judgment in Bugmy $v$ The Queen ${ }^{17}$ in 2013 makes this point unequivocally.

Legal scholars ${ }^{18}$ have been examining the issue of sentencing of Aboriginal offenders in the backdrop of Aboriginal over-representation. The commentary on Bugmy ${ }^{19}$ is that it affirmed social deprivation as a relevant consideration and worthy of mitigation in sentencing. ${ }^{20}$ However, the court fell short of accepting that judicial notice should be taken of the systemic background of deprivation of many Aboriginal offenders. ${ }^{21}$ So operationalising the 'Bugmy discount'22 in advancing social

11 Royal Commission Into Aboriginal Deaths in Custody National Report. May 1991.http://www.austlii. edu.au/au/other/IndigLRes/rciadic/\#national.

12 Australian Institute of Criminology, "Indigenous Justice in Focus, Australian Institute of Criminology 5 May 2015," http://www.aic.gov.au/crime_types/in_focus/indigenousjustice.html.

13 Ibid.

14 Andrew Dowdell, "Supreme Court Chief Justice Chris Kourakis Hits Out At South Australian Indigenous Toll”, http://www.adelaidenow.com.au/news/south-australia/supreme-court-chief-justicechris-kourakis-hits-out-at-south-australia-indigneous-jail-toll/news-story/7c47494e368a5f7d526c60eb5 175 dd 97.

15 Aboriginal and Torres Strait Islander Social Justice Commissioner Reports. Bringing Them Home Report on Stolen Generations. May 1997.

16 See Fernando (1992) 76 A Crim R 50, Houghagen v Charra (1989) 50 SASR 419, Leech v Peters (1988) 40 A Crim R 350, Rv Grose (2014) 114 SASR 92, Bugmy $v$ the Queen [2013] HCA 37, Rv Hughes; $R$ $v$ Rigney-Brown [2016] SASCFC 126, Lindsay $v$ The Queen [2015] HCA 16.

17 Bugmy $v$ the Queen, loc.cit.

18 Trevor Riley, "Aborigines and the Court: The Northern Territory Experience," Northern Territory Law Journal 2, No. 4 (2012), http:/ / sites.thomsonreuters.com.au/journals/files/2012/09/Nthn-TerritoryLaw-Jnl-Vol-2-No-4-Sep-2012.pdf

19 Bugmy $v$ the Queen, loc.cit.

20 Thalia Anthony, Lorana Bartells and Anthony Hopkins, "Lessons Lost in Sentencing: Welding Individualised Justice to Indigenous Justice," Melbourne University Law Review 16 (2015),http://www5. austlii.edu.au/au/journals/MelbULawRw/2015/16.html.

21 Ibid.

22 "Taking Indigenous Over-Imprisonment Seriously: Time For Concrete Solutions Not More Good Intentions",Editorial, Criminal Law Journal 39 No.5 (2015):231. http://sites.thomsonreuters.com.au/journals / files /2015/10/Crim-LJ-Vol-39-No-5-Contents.pdf 
disadvantage as a mitigatory factor for all Aboriginal defendants was not supported by the court. ${ }^{23}$

\section{Result and Discussion}

\subsection{The Reasonable Person Test}

\subsubsection{Biography of the Reasonable Person}

The 'reasonable person' is 'that excellent but odious character' that inhabits every nook and cranny of the common law. ${ }^{24}$ Lord Aitkin in Donoghue $v$ Stevenson ${ }^{25}$ gave us the distillation of the 'neighbour principle' -you must take reasonable care to avoid acts or omissions which you can reasonably foresee would be likely to injure your neighbour. ${ }^{26}$

The 'reasonable person' is used to assess the acceptability of behaviour in many areas of the law including, criminal law. However, this doctrine has also attracted substantial criticism from egalitarian critics and feminists insofar as it presupposes contested notions of 'normal' behaviour and may discriminate against certain classes of defendants. ${ }^{27}$

When the 'reasonable person' test is applied in the context of an Aboriginal defendant and we ask what a person would do "given the circumstances", the question that follows is, what circumstances are we talking about? It is argued that we have only a vague sketch of the 'reasonable person's biography. ${ }^{28}$ If the accused had killed his victim under provocation, he would only establish the defence if the 'reasonable person' would have been so provoked. This 'reasonable person' (a non-Aboriginal person) frequently bears none of the personal characteristics of the accused (Aboriginal person).

The 'reasonable person' test in the United Kingdom was examined by Christie ${ }^{29}$ in considering the partial defence of provocation and the 'characteristics imputed to him in the light of the accused's own character'. ${ }^{30}$ Attitudes were said to vary, that 'the doctrine weakens the legal requirement of self-control and is therefore only

23 Ibid.

24 John Gardner, "The Mysterious Case of the Reasonable Person," Univercity Toronto Law Journal 51(2001): https:// papers.ssrn.com/sol3/papers.cfm?abstract_id=1397115.

25 Donoghue $v$ Stevenson [1932] AC 562.

26 Ibid.

27 Mayo Moran, "Rethinking the Reasonable Person-An Egalitarian Reconstruction of the Objective Standard," http:/ /www.oxfordscholarship.com/view/10.1093/acprof:oso/9780199247820.001.0001/ acprof-9780199247820.

28 Ibid.

29 Sarah Christie,"Provocation-pushing the Reasonable Man Too Far?”, Journal of Criminal Law 64(2000), https://doi.org/10.1177/002201830006400410.

30 Ibid. 
acceptable where the accused has been pushed to extremes'. ${ }^{31}$ Whilst this narrow interpretation of the 'reasonable person' provides for an objective test, some would argue 'in the interests of attaining justice, characteristics of the accused should be imputed to the 'reasonable person in order to acknowledge that some people will find conduct more provoking than others, and that some individuals may have a lower threshold of self-restraint which should be taken into account'. ${ }^{32}$

In English Law, judges used to direct juries to consider the accused's conduct in the context of provocation and how a 'reasonable person' would have reacted to such provocation $^{33}$. This was a subjective test to look at the provocative effect on the conduct of the ordinary man even when the accused may have suffered some condition that made him react differently and where the ordinary man shared no personal characteristics with the accused. ${ }^{34}$

The second limb of this test was to ascertain if the accused was shown to have exercised an appropriate level of self-control and forhis test, those individual characteristics are ignored, leading to an objective assessment for this test. ${ }^{35}$ The second test gives no consideration as to whether the accused may have suffered some disability, mental health condition or social disadvantage. ${ }^{36}$

The introduction of the Homicide Act 1957 in the United Kingdom, resulted in a different judicial approach being taken, as evidenced in Camplin. ${ }^{37}$ In this case, involving the taunting and rape of a 15 year old boy, the House of Lords affirmed s3 of the Homicide Act $1957^{38}$ by giving consideration to the reasonable boy, 'a person having the power of self-control to be expected of an ordinary person of the sex and age of the accused'. ${ }^{39}$

Lord Diplock classified the 'reasonable man' as someone of either sex '... not exceptionally excitable or pugnacious', which has remained the law, but went on to mitigate the test by allowing age to be included. ${ }^{40}$ However, 'the degree of self-control

\footnotetext{
31 Ibid.

32 Ibid.

33 J. Smith and B. Hogan, Criminal Law, 8th ed, (London: Butterworths, 1996), 367.

34 Ibid.

35 Ibid.

36 See also Lindsay $v$ The Queen, loc.cit.

37 Regina (Director of Public Prosecutions) $v$ Camplin[1978] 2 All ER 168.

38 s3Homicide Act 1957 (UK), "Where on a charge of murder there is evidence on which the jury can find that the person charged was provoked (whether by things done or by things said or by both together) to lose his self-control, the question whether the provocation was enough to make a reasonable man do as he did shall be left to be determined by the jury; and in determining that question the jury shall take into account everything both done and said according to the effect which, in their opinion, it would have on a reasonable man".

39 Regina (Director of Public Prosecutions) $v$ Camplin, loc.cit.

40 Ibid.
} 
expected of him would reflect only the accused's age and sex, thus remaining as objective as possible'. ${ }^{41}$

Lord Diplock went on to state, 'the jury is entitled to act upon its own opinion of whether the objective element of provocation has been satisfied and the judge is not entitled to tell them that for this purpose the law requires them to exclude from consideration any of the circumstances or characteristics of the accused'. ${ }^{42}$

The issue of whether personal characteristics of the accused should be taken into account in the second limb test relating to the accused's exercise of self-control was considered in Smith (Morgan James). ${ }^{43}$ The defendant, who suffered from severe clinical depression, sought to rely on the defence of provocation in a murder trial. The court held that it was relevant to an assessment of the gravity of the provocation aimed at the accused - someone who is severely depressed would probably view conduct as more provocative than someone not so afflicted. ${ }^{44}$

Relevantly, the court viewed this characteristic of the accused as having an impact on the level of self-control to be expected of Smith. The court held, "when directing a jury on the law of provocation, it was no longer appropriate to direct the jury to disregard any particular characteristics of the defendant when asking whether the provocation was such as to make a reasonable person lose his self-control'. ${ }^{45}$

Christie concluded that 'English law now requires that the 'reasonable man' should have all the mental and physical characteristics of the accused in relation to the gravity of the provocation. ${ }^{46}$

In an Australian case Stingle, ${ }^{47}$ the accused, who was infatuated with his former girlfriend, stabbed her lover to death with a butcher's knife. The court relied on provisions of the Criminal Code regarding wrongful act or insult which deprives the ordinary man of self-control', ${ }^{48}$ in examining the question of provocation as a defence. ${ }^{49}$ Drawing on the judgment in Reg. $v$ Hill ${ }^{50}$ to measure the conduct of the accused against the 'ordinary man', Wilson J identified the rationale underlying the

41 Ibid.

42 Ibid.

43 Regina $v$ Smith (Morgan James) HL 27 Jul 2000.

44 Christie, op.cit.

45 Regina $v$ Smith (Morgan James), loc.cit.

46 Christie, op.cit.

47 Stingle $v R$ [1990] HCA 61.

48 S160 (2) Criminal Code (Tas), "Any wrongful act or insult of such a nature as to be sufficient to deprive an ordinary person of the power of self-control, and which, in fact, deprives the offender of the power of self-control, is provocation, if the offender acts upon it on the sudden, and before there has been time for his passion to cool".

49 Stingle v R, loc.cit.

50 Reg. v. Hill (1986) 1 SCR 313. 
objective test to be;

The objective standard, therefore, may be said to exist in order to ensure that in the evaluation of the provocation defence there is no fluctuating standard of self-control against which accused are measured. The governing principles are those of equality and individual responsibility, so that all persons are held to the same standard notwithstanding their distinctive personality traits and varying capacities to achieve the standard. ${ }^{51}$

The court added, however, that it does not mean that the objective test was intended to be applied in a vacuum or without regard to such of the accused's personal characteristics, attributes or history as serve to identify the implications and to affect the gravity of the particular wrongful act or insult. ${ }^{52}$ Conduct which may in some circumstances be quite unprovocative may be intensely so in other circumstances, hence the content and extent of the provocative conduct must be assessed from the viewpoint of the particular accused. ${ }^{53}$

In this instance the court accepted that all the relevant characteristics of the accused's age, sex, race, physical features, personal attributes, personal relationships and past history may be relevant to an objective assessment of the gravity of a particular wrongful act or insult in evaluating the gravity of the provocation. ${ }^{54}$

The role and relevance of the 'reasonable person' test was also considered in Masciantonio $v R \cdot{ }^{55}$ In this case, the minority judgment by McHugh $\mathrm{J}$ raised the curious dichotomy that the personal characteristics and attributes of the accused are relevant in determining the effect of the provocative conduct but they are not relevant in determining the issue of the self-control...the distinction has been strongly criticised on the ground that it runs counter to human reality'. ${ }^{56}$

McHugh further remarked, the "ordinary person" standard becomes meaningless if it incorporated the personal characteristics of the accused on both the issue of provocation and self-control. ${ }^{57}$ His Honour saw this as signalling inconsistency with the rationale of the objective test, which is 'too deeply entrenched in common law to be excised by judicial decision'. ${ }^{58}$

Nevertheless, in multicultural Australia, McHugh $\mathrm{J}$ accepts that 'an ordinary person is pure fiction' concluding that, 'unless the ethnic or cultural background of the accused is attributed to the ordinary person, the objective test of self-control

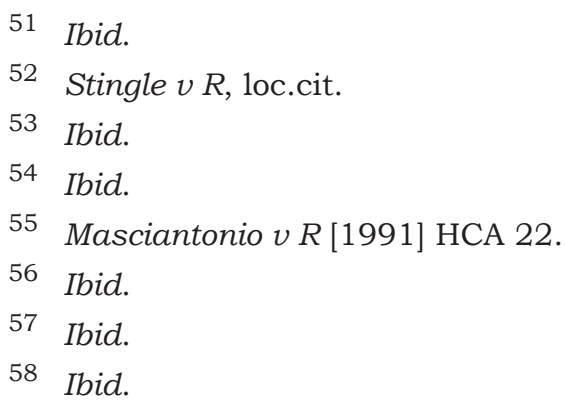


results in inequality before the law. ${ }^{59}$ Real equality before the law cannot exist when ethnic or cultural minorities are convicted or acquitted of murder according to a standard that reflects the values of the dominant class but does not reflect the values of those minorities. ${ }^{60}$

McHugh J's proposed retort, if there is a cry of one law of provocation for one class of persons and another law for a different class, is that this must be the natural consequence of true equality before the law in a multicultural society. ${ }^{61}$ His Honour noted it would be much better to abolish the objective test of self-control in the law of provocation than to perpetuate the injustice of an "ordinary person" test that did not take into account the ethnic or cultural background of the accused. ${ }^{62}$

This subjectivity and objectivity standard was described as a false dichotomy by Burke ${ }^{63}$ in looking at self-defence and the battered woman syndrome. Burke contends, the distinction is unhelpful because once we decide to employ an objective test, we must go on to consider which circumstances ought to be included in asking how the reasonable person would act'. ${ }^{64}$

An objective standard of reasonableness compares the defendant's beliefs to those of a hypothetical 'reasonable person', without taking into account the individual circumstances of the defendant. ${ }^{65}$ From a pragmatic point of view it defies common sense to ask what the 'reasonable person' would do given the circumstances if the defendant's circumstances are not described nor well understood. A "noncontextual" reasonableness standard would measure the defendant's beliefs against those of a hypothetical 'reasonable person,' without taking into account the individual characteristics of the defendant. The significance of this for an Aboriginal defendant looms large.

Aboriginal offenders are over-represented in the criminal justice system ${ }^{66}$ and the social disadvantage many suffer across a range of socio-economic factors is not well understood in mainstream Australian society. ${ }^{67}$ While the jury system may be the showpiece of the principle of impartiality, selected at random, in practice very

\footnotetext{
59 Ibid.

60 Ibid

61 Ibid

62 Ibid.

63 Alafair S. Burke, "Rational Actors, Self Defense and Duress: Making Sense Not Syndromes Out of the Battered Woman", North Carolina Law Review 81 (2002), http:/ / scholarlycommons.law.hofstra.edu/ faculty_scholarship/165.

64 Ibid

65 Ibid

66 Australian Institute of Criminology,loc.cit.

67 In Bugmy $v$ the Queen [2013] HCA 37 the court held social deprivation does not diminish over time and repeat offending.
} 
few Aboriginal people make up the composition of a trial jury. ${ }^{68}$ It follows that the general level of understanding of Aboriginal disadvantage may not be present in a jury trial involving an Aboriginal defendant. The Australian Law Reform Commission highlighted its concern about the underrepresentation of Aboriginal people on juries despite being heavily overrepresented in the criminal justice system. ${ }^{69}$

\subsubsection{A Heuristic Theory to Define the Reasonable Person}

Nourse, ${ }^{70}$ challenges the conventional notion of the 'reasonable person', suggesting an alternative approach based on heuristic theory and argues that equality will be better served through a normative analysis of the reasonable person instead of through the subjectivity/objectivity debate. ${ }^{71}$

Traditionally the subjectivity/objectivity debate was focussed on the identity of the 'reasonable person', whether to include characteristics of age or sex or culture. Jurisdictions sensibly applied a hybrid model of subjectivity and objectivity because, if the subjective component of the 'reasonable person' standard includes the norms of the defendant, no trial would be possible or if any contextual component were eliminated, extreme versions of the objective standard could remove consideration of physical facts. ${ }^{72}$ The jury is tasked to judge the defendant by the standards of the 'reasonable person', but importantly, the "reasonable person "in the situation." the case of an Aboriginal defendant, the jury, must reasonably, give consideration to the context of social disadvantage suffered and the impact this may have on the conduct of the defendant from such circumstances.

Nourse asserts that scholars have made an 'analytic mistake 74 by assuming the 'reasonable person is a person; he is an 'institutional heuristic of anthropomorphic form'. ${ }^{75}$ If the reasonable person is a 'heuristic for law's institutional aims ${ }^{76}$, in criminal law, he is able to 'adjudicate the relationship of the defendant to the state'77 applying majoritarian norms and individualise, by considering the defendant in the

68 Mark Israel, "Ethnic Bias in Jury Selection in Australia and New Zealand", International Journal of the Sociology of Law 26 (1998), https://doi.org/10.1006/ijs1.1998.0057

69 Australian Law Reform Commission Report on Aboriginal Customary Law Report 31<https: / / www. alrc.gov.au/sites/default/files/pdfs/publications/ALRC31.pdf>.

70 Victoria Nourse, After the Reasonable Man: Getting over the subjectivity/objectivity question, New Criminal Law Review 11, No1 Winter 2008 <http://scholarship.law.georgetown.edu/cgi/viewcontent. cgi?article=2133\&context $=$ facpub $>$.

71 Ibid.

72 Victoria Nourse, "After the Reasonable Man: Getting Over the Subjectivity/Objectivity Question," New Criminal Law Review 11, No.1 (2008), http://scholarship.law.georgetown.edu/cgi/viewcontent.cgi?ar ticle $=2133 \&$ context $=$ facpub.

73 Ibid.

74 Ibid.

75 Ibid.

76 Ibid.

77 Ibid. 
situation. ${ }^{78}$ However, this process of both 'reflecting and restraining ${ }^{79}$ majoritarian norms is 'a complex task for a single metaphorical person to handle'. ${ }^{80}$

A system devised to optimise all information and enable decision making without reference to the context is said to lack ecological rationality, i.e. a rational decision which considers the rules but does not take into account the environment or context. Nourse raises the question of whether prior victimisation could be classified as part of the characteristics of the 'reasonable person' by exploring two cases, State $v$. Norman ${ }^{81}$ and People $v$ Goetz. ${ }^{82}$

In the first, the defendant, after years of domestic tyranny involving degrading abuse in which she was prostituted, deprived of food, made to sleep on the floor and driven to attempt suicide, finally killed her husband in his sleep. ${ }^{83}$ In the second case, Goetz shot at four African-American youths on a subway after one of them approached him and said, 'Give me five dollars', because he carried a fear based on a previous experience of being maimed. ${ }^{84}$

Because the norm is that most individuals are not victims in the sense of the two defendants described, it may be argued that prior victimisation should not be part of the characteristics of the 'reasonable person'. However this is not so; in criminal law prior threats have been admissible evidence. ${ }^{85}$ This begs the question, what norms are we judging the reasonableness on? What it does reveal is that the "characteristics" question, in its aim to be normatively agnostic, may yield results quite at odds with standard legal doctrine. ${ }^{86}$

Nourse argues that norms relied on in judging reasonableness is influenced by "cultural default rules's7 which are silently invoked, they come from the "veil of relationships'88, from the 'institution of family and gender'89 and both mediate and swamp the application of law. ${ }^{90}$ All this does not mean the metaphor of the 'reasonable person' loses its place in enabling an emotional identification with the defendant

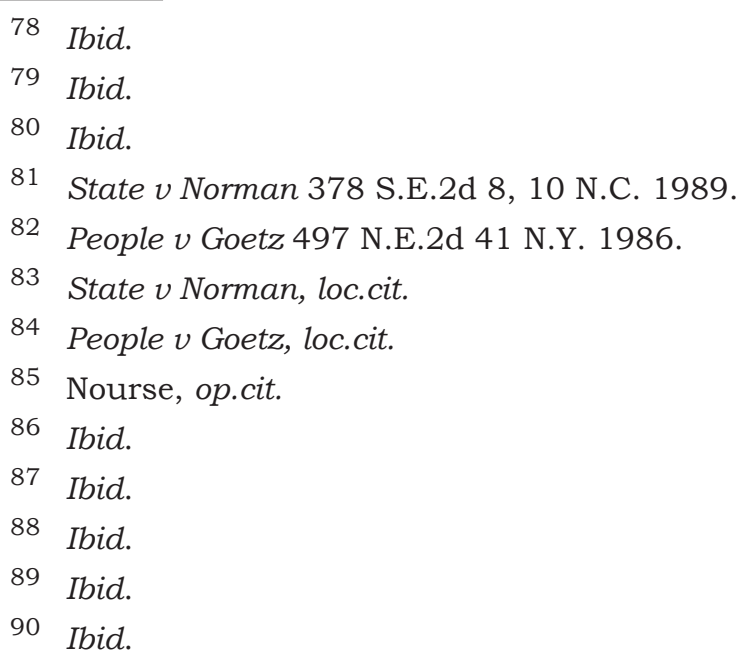


and for the jury to decide between the law-abiding and the law-breaker. ${ }^{91}$ But what it does is to proffer caution in scrutinising reasonableness without contextualising it.

\subsection{Equality}

Aristotle (384-322 $\mathrm{BCE}$ ) said, 'the worst kind of equality is to try and make unequal things equal'. ${ }^{92}$ Aristotle's conception of justice has two strings; conduct which conforms to an authoritative rule of human conduct which makes man act righteously (moral justice) and justice that signifies equality, where a just law in action lies between defect and excess. ${ }^{93}$ The principle of equality creates a moral criterion for the administration of human conduct and by consequence, our moral evaluation of an action is influenced by our personal views as to how we measure the correctness of a particular action as to where it exceeds or falls short of the mean (i.e. the reasonable person) as expressed by the principle of equality. ${ }^{94}$

Justice, according to Aristotle, is a virtue, a social virtue, as it involves a relationship with others, as it is displayed to others not towards oneself. ${ }^{95}$ In his theory of law, Aristotle distinguishes between "commutative justice"96 and 'distributive justice ${ }^{97}$; unlike the latter form, the former concept of justice ignores the rank of the persons involved in the dispute. ${ }^{98}$

The principle of justice and equality, on the other hand, takes account of the two claims and the two persons involved; should these two people be of unequal rank, they cannot be treated alike, as equality demands that only equals be treated equally. ${ }^{99}$ Equality in justice apportions burdens according to the individual's ability to carry them and accords support that is proportional to the needs of such individuals. ${ }^{100}$ This is the underpinning of 'distributive justice'.

Aristotle's contemplation of 'strict equality' is where justice rests upon the principle that all persons involved are absolute equals and the law purely examines the nature of loss or damage by the relative worth of differing claims and restores

$\begin{array}{ll}91 & \text { Ibid. } \\ 92 & \text { Chroust and Osborn, op.cit } \\ 93 & \text { Ibid. } \\ 94 & \text { Ibid. } \\ 95 & \text { Ibid. } \\ 96 & \text { Ibid. } \\ 97 & \text { Ibid. } \\ 98 & \text { Ibid. } \\ 99 & \text { Ibid. } \\ 100 & \text { Ibid. }\end{array}$


equality. ${ }^{101}$ Conversely, the principle of 'distributive justice' gives consideration to the two claims and the two claimants involved, and where the two claimants are not equals, 'proportionate equality' is dispensed. ${ }^{102}$ According to Aristotle, 'men judge erroneously' ${ }^{103}$ when people are taken out of the consideration.

\subsubsection{Equal Justice - A Bedrock Issue}

'Like should be treated alike and relevant difference treated rationally different. Equality is a protean word, used specifically in the context of the application of law'. ${ }^{104}$

In reflecting on the judgments of Bugmy $v$ The Queen ${ }^{105}$ and Munda $v$ Western Australia, ${ }^{106}$ the Hon Rothman $\mathrm{J}$ alluded to the fundamentals in bringing into effect the principle of equal justice. ${ }^{107}$

In Munda ${ }^{108}$ the court held,

'Mitigation factors must be given appropriate weight, but they must not be allowed to lead to the imposition of a penalty which is disproportionate to the gravity of the instance offence. It would be contrary to the principles stated by Brennan $\mathrm{J}$ in Neal to accept that Aboriginal offending is to be viewed systematically as less serious than offending by persons of other ethnicities. To accept that Aboriginal offenders are in general less responsible for their actions than other persons would be to deny Aboriginal people their full measure of human dignity. It would be quite inconsistent with the statement of principle in Neal to act upon a kind of racial stereotyping which diminished the dignity of individual offenders by consigning them, by reason of their race and place of residence, to a category of persons who are less capable than others of decent behaviour. Further, it would be wrong to accept that a victim of violence by an Aboriginal offender is somehow less in need, or deserving of such protection and vindication as the criminal law can provide'. ${ }^{109}$

In Bugmy ${ }^{110}$ the court said,

'Of course, not all Aboriginal offenders come from backgrounds characterised by the abuse of alcohol and alcohol-fuelled violence. However, Wood J was right to recognise both that those problems are endemic in some Aboriginal communities, and the reasons which tend to perpetuate them. The circumstance that an offender has been raised in a community surrounded by alcohol abuse and violence may mitigate the sentence because his or her moral culpability

\footnotetext{
101 Ibid.

102 Ibid.

103 Ibid.

104 Stephen Rothman AM, op.cit.

105 Bugmy v The Queen [2013] HCA 37.

106 Munda $v$ Western Australia [2013] HCA 38.

107 Stephen Rothman AM, op.cit.

108 Munda $v$ Western Australia [2013] HCA 38.

109 Munda $v$ Western Australia [2013] HCA 38.

110 Bugmy $v$ The Queen [2013] HCA 37.
} 
is likely to be less than the culpability of an offender whose formative years have not been marred in that way.

Mr Fernando was a resident of an Aboriginal community located near Walgett in far-western New South Wales. The propositions stated in his case are particularly directed to the circumstances of offenders living in Aboriginal communities. Aboriginal Australians who live in an urban environment do not lose their Aboriginal identity and they, too, may be subject to the grave social difficulties discussed in Fernando. Nonetheless, the appellant's submission that courts should take judicial notice of the systemic background of deprivation of Aboriginal offenders cannot be accepted. It, too, is antithetical to individualised justice. Aboriginal Australians as a group are subject to social and economic disadvantage measured across a range of indices, but to recognise this is to say nothing about a particular Aboriginal offender. In any case in which it is sought to rely on an offender's background of deprivation in mitigation of sentence, it is necessary to point to material tending to establish that background. It will be recalled that in the Court of Criminal Appeal the prosecution submitted that the evidence of the appellant's deprived background lost much of its force when viewed against the background of his previous offences. On the hearing of the appeal in this Court the Director did not maintain that submission. The Director acknowledges that the effects of profound deprivation do not diminish over time and he submits that they are to be given full weight in the determination of the appropriate sentence in every case'. ${ }^{111}$

Rothman $\mathrm{J}$ remarks that equality in the application of the law is a fundamental aspect of the exercise of judicial powers, citing $R v$ Clarke; ${ }^{112}$

'Equal justice' embodies the norm expressed in the term 'equality before the law'. It is an aspect of the rule of law. It was characterised by Kelsen as 'the principle of legality, of lawfulness which is immanent in every legal order'. It has been called 'the starting point of all other liberties'....In Wong $v$ The Queen, ${ }^{113}$ the court said, 'equal justice requires identity of outcome in cases that are relevantly identical. It requires different outcomes in cases that are different in some relevant aspect... as with the norm of 'equal justice', which is its foundation, the parity principle allows for different sentences to be imposed upon like offenders to reflect the different degrees of culpability and/or different circumstances'. ${ }^{114}$

Though having no argument with the way the High Court dealt with cases discussed above, Rothman J raises the Canadian Supreme Court's treatment of s718.2(e) of the Canadian Criminal Code, where Aboriginality is accepted as a factor in sentencing. ${ }^{115}$ The case of $R v$ Glade $^{116}$ is on point. Here the court held,

\footnotetext{
111 Bugmy $v$ The Queen [2013] HCA 37, paras 40-42.

${ }^{112} R v$ Clarke [2013] NSWCCA 260.

113 Wong $v$ The Queen [2001] HCA 64.

114 Rothman AM,loc. cit.

115 Ibid.

${ }^{116} R v$ Gladue, loc.cit.
} 
'...it would be a misapplication of $\mathrm{s} 718.2(\mathrm{e})$ to automatically reduce a sentence or exclude imprisonment merely because a particular accused is of Aboriginal descent. However the provision calls on a sentencing judge to undertake a fundamentally different analysis when sentencing an Aboriginal person, because Aboriginal persons have unique circumstances. Such an analysis must begin with an assessment of the degree to which systemic and background factors unique to Aboriginal offenders have played a role in a particular accused's life and appearances before the court. These factors will often include poverty, substance abuse, lack of education and lack of employment opportunities. Where these factors have played a significant role in an Aboriginal accused's life, the analysis shifts to an assessment of the availability of appropriate alternatives to imprisonment as a sentence'. ${ }^{117}$

In this case, the sentencing judge unduly restricted the application of s718.2(e) to offenders residing on reserves and took no systemic or background factor unique to Aboriginal persons into account in crafting the sentence, resulting in an error in law. ${ }^{118}$

In 2012 the Supreme Court of Canada revisited section 718(2)(e) in $R v$ Ipeelee,${ }^{119}$ and reaffirmed and expanded upon the principles in Gladue, ${ }^{120}$

'Section 718.2(e) is not simply a codification of existing jurisprudence, it is remedial in nature. Its purpose is to ameliorate the serious problem of overrepresentation of aboriginal people in prisons, and to encourage sentencing judges to have recourse to a restorative approach to sentencing. There is a judicial duty to give the provision's remedial purpose real force'. ${ }^{121}$

The Supreme Court of Canada continued,

'Section 718.2(e) of the Criminal Code was implemented in order to address the overrepresentation of Aboriginal people in the Canadian criminal justice system. The restorative justice approach including the consideration of the Aboriginal person's status as such as explained in $R v$ Gladue. ${ }^{122}$ The Supreme Court called upon judges to consider different methods in sentencing Aboriginal offenders and required them to consider the possibility of systemic and background factors having a role in an Aboriginal accused being involved in the criminal justice system. The failure of the legislative and judicial efforts to address the overrepresentation of Aboriginal in the criminal justice system is partially due to fundamental misunderstanding and misapplication of the laws found in $R v$ Gladue $^{123}$ and s718.2(e) of the Code'. ${ }^{124}$

'Under s718.2(e) trial judges have a statutory duty to consider the unique

117 Ibid.

118 Rothman AM, loc.cit.

119 R $v$ Ipeelee, loc. cit.

120 "Summary of R v Gladue by the SCC in the Ipeelee Case", http:/ /www.gladueprinciples.ca/downloads /ipeelee-gladue-summary.pdf.

121 Ibid.

${ }^{122} R v$ Gladue,loc. cit.

123 Ibid.

124 Ibid. 
circumstances of Aboriginal offenders in sentencing. To fail to apply $R v$ Gladue would $^{125}$ result in unfit sentences that are not consistent with the principle of proportionality and would be a violation of that statutory duty. The error of failing to consider and apply Gladue ${ }^{126}$ principles would justify appellate intervention'. ${ }^{127}$

With the principles from Ipeele $e^{128}$ and Gladue ${ }^{129}$ in mind, Rothman J returned to the judgments in Bugmy ${ }^{130}$ and Munda, ${ }^{131}$ mindful that although there is an acceptance that the environment of alcohol and abuse has an impact on Aboriginal accused, on the effects of discrimination, exclusion and disempowerment the court is mute. ${ }^{132}$

Rothman $\mathrm{J}$ makes reference to the 'Baumeister tests', ${ }^{133}$ a psychological tool, shown to disclose that social exclusion and/or rejection affects behaviour and in the context of the law, the matter of moral culpability, relevant to sentencing. ${ }^{134}$ His Honour reaffirms the need for judicial officers to be vigilant, not relying on the mere fact of Aboriginality but more so on the background of the Aboriginal offender being sentenced. ${ }^{135}$

The challenge for Aboriginal legal services is to ensure the best information comes before the court so that, with good information and good advocacy, the Aboriginal offender does not receive unfair treatment. As s718.2(e) has shown, where the unique circumstances of Aboriginal offenders are recognised and acknowledged, it is not a distortion of the principles of equal justice to have regard to them. ${ }^{136}$

\subsubsection{Equal Justice and Cultural Diversity}

On the achievement of equal justice in a demographically diverse nation such as Australia, the former Chief Justice of the High Court of Australia, Hon Robert

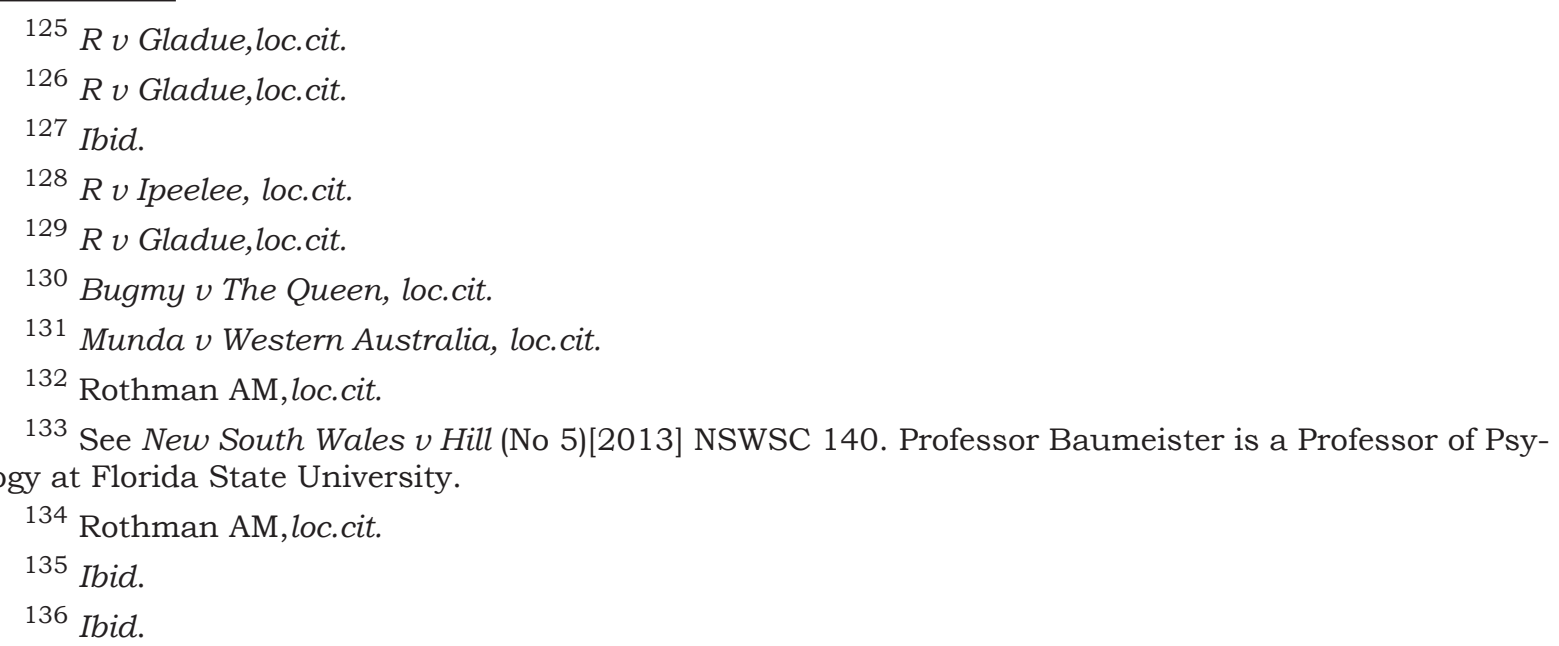


French AC, said that it requires all players in the legal system to be aware of and respond to the challenges of cultural differences. ${ }^{137}$ Curiously, the symbol of Justice is a goddess blindfolded, depicting equality before the law and thus blind to differences, including cultural attributes. ${ }^{138}$

The Australian Constitution allows the Commonwealth Parliament to make laws for people of any race and such laws would not offend against the principle of equality before the law. ${ }^{139}$ Objective criteria for liability in the criminal law, such as reasonableness, may be applied from the perspective of what can be called the dominant culture'. ${ }^{140}$ This may disadvantage individuals from different cultural groups who have different values. But as French $\mathrm{CJ}$ expressed, any concern about the standards or values to which all who enter Australia are expected to conform and if that is the reflection of the dominant culture, it is the price of the benefits which Australian society confers. ${ }^{141}$

In its 1992 report, the Australian Law Reform Commission concluded;

'a proliferation of different standards against which to judge the reasonableness or otherwise of a person's behaviour in the criminal law is undesirable. To apply different standards to different groups would lessen the protection afforded to all by the criminal law'. ${ }^{142}$

However French CJ, taking from both Bugmy ${ }^{143}$ and Munda, ${ }^{144}$ believes that,

The proposition that the Aboriginality of a particular offender may be considered, not as a mitigating factor itself, but as a means of identifying the circumstances of the offender that are relevant to sentencing is applicable to ethnicity or culture, which in a similar way may shed light upon the existence or non-existence of factors traditionally regarded as relevant to the exercise of sentencing discretions'. ${ }^{145}$

Achieving equal justice involves how substantive law and the legal system embraces cultural diversity, although law reform is always fraught, so we must look to administrators within the criminal justice system who may have a direct and beneficial effect on this goal. ${ }^{146}$ French $\mathrm{CJ}$ is hopeful the establishment of the Judicial Council

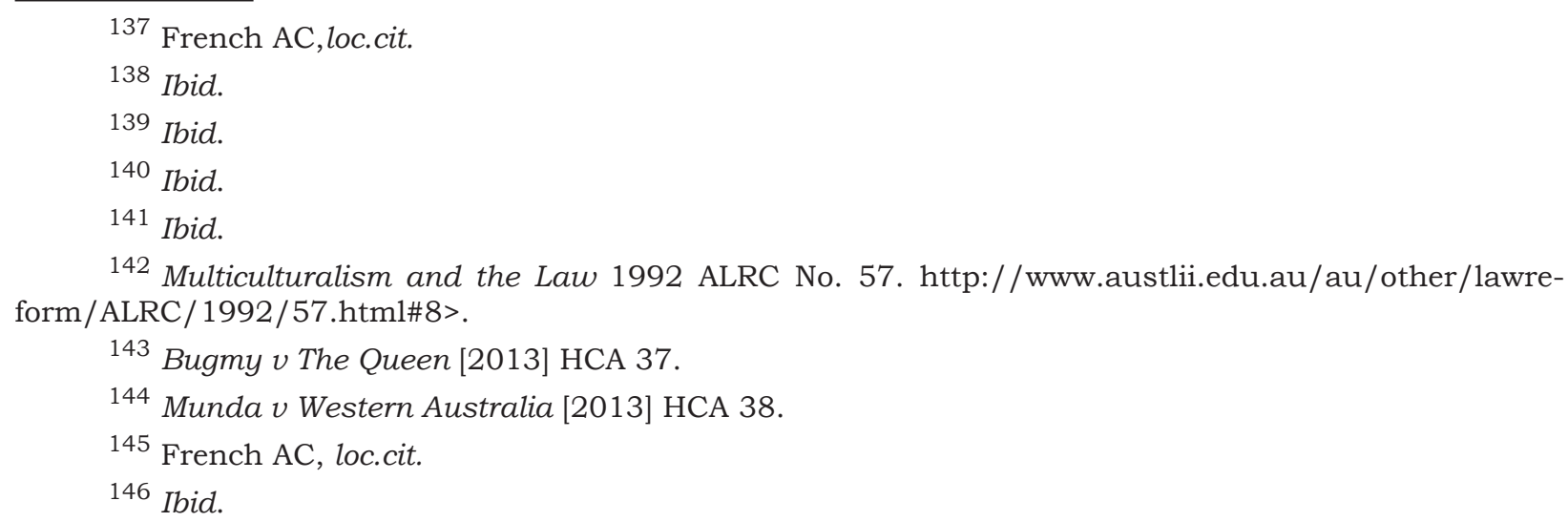


on Cultural Diversity would go some way to do equal justice in a culturally complex community. ${ }^{147}$

The International Covenant on Civil and Political Rights ${ }^{148}$ has provisions for the recognition and protection of cultures as a norm in international law, to ensure legal respect for cultural differences. ${ }^{149}$ In a reminder of Aristotelian formal equality, the former Federal Court Judge and President of the Human Rights and Equal Opportunity Commission, the Hon John Von Doussa pointed out,

it is part of a judge's function to ensure, as far as possible, that there is equality between parties to litigation. At times this requires careful and sympathetic assessment of the potential disadvantage suffered by a party, and intervention to achieve a fair balance. None of this is possible unless the judge in a particular case is made aware of, or recognises, factors that might produce inequality'. ${ }^{150}$

\subsection{Sentencing Principles and Individualised Justice}

Laws on sentencing generally give consideration to the seriousness of the offence, adequate punishment, community protection, general and personal deterrence and rehabilitation of the offender. ${ }^{151}$

The decision in $R v$ Fernando ${ }^{152}$ remains one of the most influential decisions on the relationship between Aboriginality and sentencing under criminal law, where Wood CJ set out the Fernando principles. ${ }^{153}$ These principles makes several significant points about the same sentencing principles being applied in every case irrespective of the identity of a particular offender, but that the relevance of Aboriginality is not necessarily to mitigate punishment but to shed light on the particular offence and circumstances of the offender from a deprived background with grave social difficulties and endemic presence of alcohol in communities. ${ }^{154}$

For completeness, the Fernando ${ }^{155}$ principles of 1992 are thus;

'(A) The same sentencing principles are to be applied in every case irrespective of the identity of a particular offender or his membership of an ethnic or other group

\footnotetext{
147 Ibid.

148 International Covenant on Civil and Political Rights, Art. 27.

149 Ibid.

150 Von Doussa J, Launch of the Supreme Court Equal Treatment Benchbook, speech delivered at Banco Court Supreme Court of Queensland on 15 February 2006, https://www.humanrights.gov.au/ news/speeches/launch-supreme-court-equal-treatment-benchbook.

${ }^{151}$ Christopher Charles, The law of sentencing applied to Aboriginal people in South Australia<http: / / aija.org.au/Ind\%20Courts\%20Conf\%2013/Papers/Charles.pdf>.speeches/launch-supreme-court-equal-

${ }^{152}$ R v Fernando (1992) 76 Australian Criminal Reports 58.

153 Richard Edney, "The Retreat From Fernando and the Erasure of Indigenous Identity In Sentencing," Indigenous Law Bulletin 6 No. 17 (2006), http:/ /www.austlii.edu.au/au/journals/IndigLawB/2006/11.html.

${ }^{154} R v$ Fernando, loc.cit.

155 Ibid.
} treatment-benchbook. 
but that does not mean that the sentencing court should ignore those facts which exist only by reason of the offenders' membership of such a group.

(B) The relevance of the Aboriginality of an offender is not necessarily to mitigate punishment but rather to explain or throw light on the particular offence and the circumstances of the offender.

(C) It is proper for the court to recognise that the problems of alcohol abuse and violence which to a very significant degree go hand in hand within Aboriginal communities are very real ones and their cure requires more subtle remedies than the criminal law can provide by way of imprisonment.

(D) Notwithstanding the absence of any real body of evidence demonstrating that the imposition of significant terms of imprisonment provides any effective deterrent in either discouraging the abuse of alcohol by members of the Aboriginal society or their resort to violence when heavily affected by it, the courts must be very careful in the pursuit of their sentencing policies to not thereby deprive Aboriginals of the protection which it is assumed punishment provides. In short, a belief cannot be allowed to go about that serious violence by drunken persons within their society are treated by the law as occurrences of little moment.

(E) While drunkenness is not normally an excuse or mitigating factor, where the abuse of alcohol by the person standing for sentence reflects the socioeconomic circumstances and environment in which the offender has grown up, that can and should be taken into account as a mitigating factor. This involves the realistic recognition by the court of the endemic presence of alcohol within Aboriginal communities, and the grave social difficulties faced by those communities where poor self-image, absence of education and work opportunity and other demoralising factors have placed heavy stress on them, reinforcing their resort to alcohol and compounding its worst effects.

(F) That in sentencing persons of Aboriginal descent the court must avoid any hint of racism, paternalism or collective guilt yet must nevertheless assess realistically the objective seriousness of the crime within its local setting and by reference to the particular subjective circumstances of the offender.

(G) That in sentencing an Aborigine who has come from a deprived background or is otherwise disadvantaged by reason of social or economic factors, or who has little experience of European ways, a lengthy term of imprisonment may be particularly, even unduly, harsh when served in an environment which is foreign to him and which is dominated by inmates and prison officers of European background with little understanding of his culture and society or his own personality.

(H) That in every sentencing exercise, while it is important to ensure that the punishment fits the crime and not to lose sight of the objective seriousness of the offence in the midst of what might otherwise be subjective circumstances, full weight must be given to the competing public interest to rehabilitation of the offender and the avoidance of recidivism on his part'. ${ }^{156}$ 
The retreat from Fernando ${ }^{157}$ ten years later by the New South Wales Court of Criminal Appeal was noted in $R v$ Ceissman ${ }^{158}$ and $R v$ Pitt. ${ }^{159}$ In both instances, Wood CJ observed, 'the sentencing judge was at risk of misapplying Fernando 160 'because the background facts indicated the respondent's heritage was only "partAboriginal" and 'nothing of an exceptional kind in the Aboriginality or upbringing of the applicant that called for any particular mitigation of sentence'. ${ }^{161}$

The judicial reasoning was described as problematic because, if accepted, it meant the offender would have to argue for 'exceptionality' in his background history to attract Fernando ${ }^{162}$ considerations. ${ }^{163}$ The test is indeterminate but appears to impute a new test on the degree of social deprivation necessary to attract the operation of these principles. ${ }^{164}$ Even concerning is that such judicial decisions attempt to define contemporary Aboriginal experience and who may be entitled to rely upon Aboriginality for the purpose of sentencing. ${ }^{165}$

The Royal Commission into Aboriginal Deaths in Custody stridently recommended imprisonment should be a sentence of last resort. ${ }^{166}$ Bagaric ${ }^{167}$ examined the rise and rise of Aboriginal incarceration rates and a baseline study ${ }^{168}$ revealed Aboriginal offenders are more than twice as likely to be sentenced to prison as non-Aboriginal offenders when they appear in court. ${ }^{169}$

He proposed two reforms; to reduce the impact of prior convictions in the 'sentencing calculus', ${ }^{170}$ as it cannot justify a sentence beyond that which is proportionate to the gravamen of the instant offence, and to more acutely operationalise the 'Bugmy discount', ${ }^{171}$ as the court reasoned, such offenders are sometimes less culpable because their formative years may have been marred by being subjected to negative influences, impairing their capacity to mature and diminishing their moral culpability. ${ }^{172}$

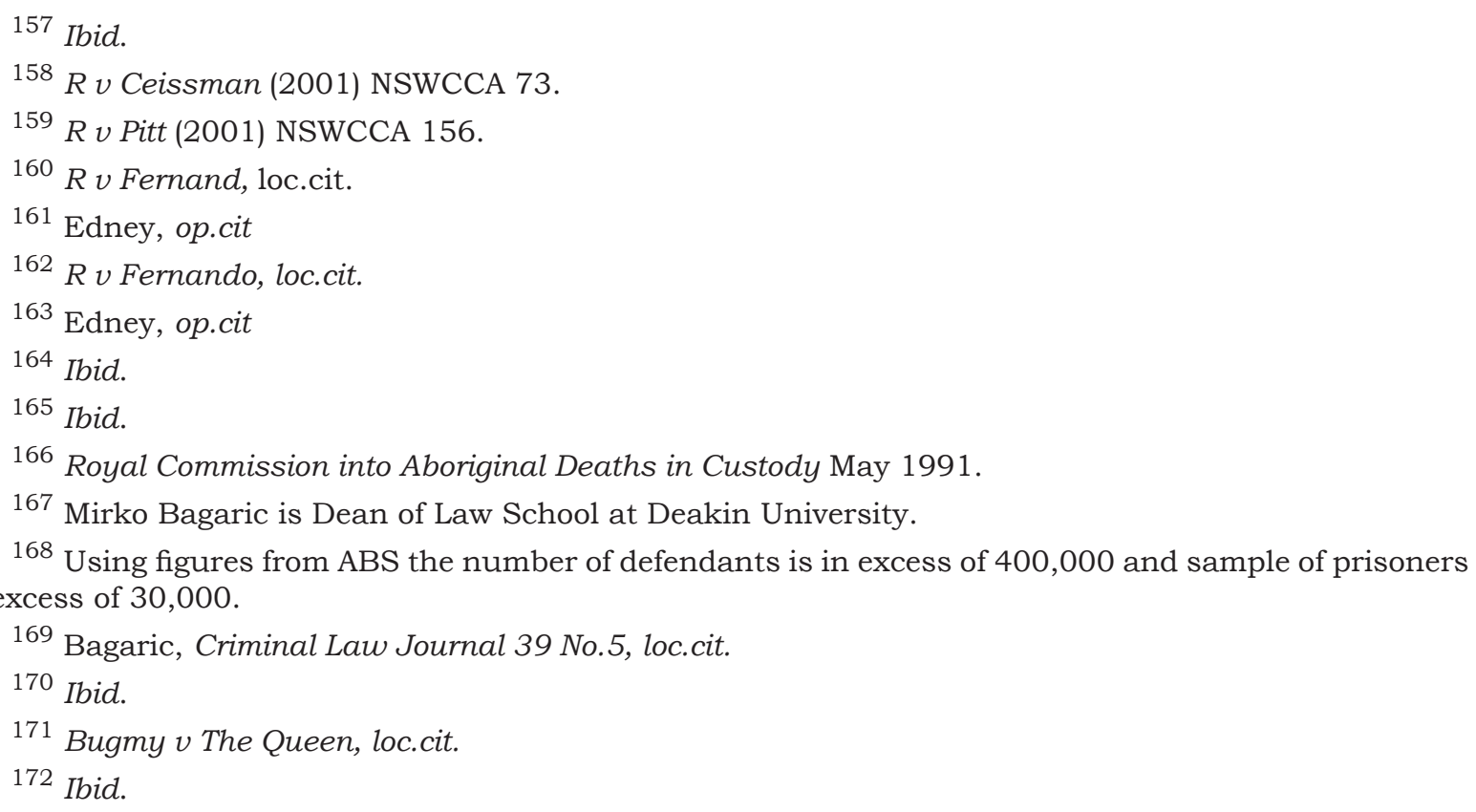


The quest for equal justice in sentencing had its champion in 1893 in Justice Charles Dashwood, sitting as the Northern Territory Judge of the South Australian Court, who recognised the difficulties in providing justice to Aboriginal accused. ${ }^{173}$ The attitude of justice administrators at that time is reflected in the illegal practice where Aboriginal witnesses were kept in custody 'for their own protection and to prevent them getting away'. ${ }^{174}$

A significant advance came in 1976 with Justice Forster's judgment in $R v$ Anunga ${ }^{175}$ and the Anunga Rules ${ }^{176}$ which provide guidance to police officers when interrogating Aboriginal persons they have apprehended. Riley $\mathrm{CJ}$, reflecting on the centenary of the Supreme Court of the Northern Territory, noted, in the exercise of power to ensure a fair trial, judges have become more interventionist, taking tighter control over questioning of Aboriginal witnesses and being alert to reduce the weight of answers to questions where gratuitous concurrence is evident. ${ }^{177}$

Good advocacy, in telling the court why the defendant has not acted as a reasonable person would, is providing the court with all the relevant information such that it allows the judge to exercise the widest discretion by taking into account issues (intergenerational alcohol abuse, violence, stolen generations, child protection, loss of kinship and country), context and characteristics of the Aboriginal accused.

Individualised justice requires judges to consider factors like social deprivation, overrepresentation in jails, historical dispossession and colonisation for Aboriginal offenders. In the Northern Territory Court of Criminal Appeal in $R v G J,{ }^{178}$ the wide exercise of judicial discretion is evident in having regard to Aboriginality;

it is not in contention that where customary law conflicts with Territory law, the latter must prevail. Similarly, there is no doubt that an Aboriginal person who commits a crime because he is acting in accordance with traditional Aboriginal law is less morally culpable because of that fact'. ${ }^{179}$

This echoes Justice Brennan's judgment in Neal $v$ The Queen, ${ }^{180}$ where his Honour said the same sentencing principles must be applied in every case, but distinguishing that courts are bound to take into account all material facts, including facts that exist only by reason of the offender's membership to an ethnic or other group. ${ }^{181}$

${ }^{173}$ Riley, op.cit.

174 Ibid.

${ }^{175} R v$ Anunga (1976) 11 ALR 412.

176 The Anunga Rules has been described by Professor Les McCrimmon as 'a uniquely Territorian addition to the common law of evidence'.

177 Riley, op.cit.

${ }^{178} R v G J(2005) 16$ NTLR 230 at 30.

179 Ibid.

180 Neal $v$ The Queen 149 CLR 305 at 326.

${ }^{181}$ Ibid. 
The cases referred to in this article, including Bugmy $v$ The Queen ${ }^{182}$ and Masciantonio $v$ The Queen ${ }^{183}$ typify the High Court's position, according to Martin CJ, that culture is legally relevant as a principle of consideration in the defence of provocation. ${ }^{184}$ They also reassert the principle of individualised justice.

'Justice if not individual is nothing'185, yet to a considerable extent current judicial attitudes to sentencing Aboriginal people, in practice and in principle, fail to properly recognise or fully appreciate the extent and causes of disadvantage and its relevance in individual cases. ${ }^{186}$ In posing the question whether there is not enough judicial notice in the sentencing of Aboriginal offenders, Judge Stephen Norris, QC, argues there is scope within the current legislative constraints and legitimate sentencing discretion for more extensive use of judicial notice with reference to Bugmy ${ }^{187}$ and Munda, ${ }^{188}$ to properly assess both the objective and subjective circumstances of offending and offenders to enhance individualised justice. ${ }^{189}$

\subsection{Contemporising the Reasonable Person}

In writing about how Lord Aitkin's judgments still guide Australian law, Applegarth ${ }^{190}$ observes from many of his judicial decisions, Lord Aitkin considered 'that principled decisions should rest upon the judicial officer having an understanding of the conditions of life of ordinary people'. ${ }^{191}$ In his judicial career Lord Aitkin sought to determine legal disputes in a manner which accorded with common sense, motivated by a desire to achieve justice. ${ }^{192}$

Applegarth writes, in developing the law, he was a progressive in the sense that he believed in the potential of law to improve society. ${ }^{193}$ It was Lord Aitkin who

182 Bugmy v The Queen, loc.cit.

183 Masciantonio $v$ The Queen.

184 Wayne Martin AC, Access to Justice in Multicultural Australia, Judicial Council on Cultural Diversity, Cultural Diversity and Law Conference on 13 March 2015, http://www.supremecourt.wa.gov. au/_files/Speeches_Cultural\%20Diversity\%20and\%20the\%20Law\%20Conference\%20-\%20Access\%20 to $\% 2$ Justice $\% 20$ in $\% 20$ Multural\%20Australia\%20by $\% 20$ the $\% 20$ Hon $\% 2$ Wayne $\% 20$ Martin $\% 20 \mathrm{AC}, \% 20$ Chief\%20Justice\%20of\%20Western\%20Australia.pdf.

185 Kable v DPP (1995) 38 NSWLR 374.

186 Stephen Norris QC, Sentencing Aboriginal Offenders -Not Enough 'Judicial Notice’? Judicial Conference of Australia Colloquium, Sydney 13 October 2013.

187 Bugmy v The Queen [2013] HCA 37.

188 Munda $v$ Western Australia [2013] HCA 38.

189 Stephen Norris QC, op.cit.

190 P D T Applegarth, "Lord Aitkin: Principle and Progress", The Australian Law Journal 90 No.10 (2016): http://sites.thomsonreuters.com.au/journals/files/2016/10/ALJ-Vol-90-No-10-Contents-final.pdf.

191 Ibid.

192 Ibid.

193 Ibid. 
gave us 'the most influential common law decision of the twentieth century'194 in Donoghue $v$ Stevenson, ${ }^{195}$ the case that established the doctrine of the "neighbour principle' which morphed into the 'reasonable person' test.

Taking Nourse's proposition of the reasonable person as an 'institutional heuristic' and combining the genius of Lord Aitkin's principled decisions motivated by a desire to achieve justice, it may be time to contemporise the characteristics of the 'reasonable person' as the law would apply to the class of Aboriginal defendants. At first glance the task may appear an impossible dream, but this article has demonstrated there is a growing body of case law ${ }^{196}$ pointing to the principle that like cases should be treated alike, but relevant differences should be treated differently. ${ }^{197}$ This breeds intellectual confidence to postulate a time when consolidation of relevant legal precepts and principles; when Fernando principles', ${ }^{198}$ Anunga Rules ${ }^{199}$ and case law persuading the precedence of individualised justice outcomes in Bugmy 200 and $M u n d a^{201}$ will take the generalities of Aboriginal disadvantage, adapt the objective test to take into account Aboriginal identity and crystalise it to craft a contemporary Aboriginalised 'reasonable person'.

Sentencing is an inherently individualised process which gives permission, as the cases show, to consideration of the generalities of Aboriginal disadvantage as applied to the particular Aboriginal offender before the court. By letting go of 'the intellectual tradition of defining a legal standard by reference to a hypothetical person $^{202}$ and contemporising the reasonable person manifesting Aboriginal identity, sentencing processes gain to move closer to the Aristotelian formal equality, enhancing individualised justice and achieving equal justice.

\section{Conclusion}

This article has explored the Aristotelian question of formal equality in achieving equal justice in sentencing outcomes for Aboriginal defendants and the relevance of contemporising the reasonable person test, clothed in Aboriginal identity. This reimagined reasonable person would speak to the values of kinship and cultural obligations, understand social deprivation and exclusion and its consequences and

\footnotetext{
194 Ibid.

195 Donoghue $v$ Stevenson, loc.cit.

196 See $R v$ Hughes, loc.cit; $R v$ Rigney-Brown, loc.cit.

197 Rothman AM, loc.cit.

198 R v Fernando, loc.cit.

${ }^{199} R v$ Anunga, loc. cit.

200 Bugmy $v$ The Queen, loc.cit.

201 Munda $v$ Western Australia, loc.cit.

${ }^{202}$ Hall v. Brooklands Auto-Racing Club (1933) 1 KB 205.
} 
acknowledge that, in some instances, the defendant's obedience to Aboriginal Law ${ }^{203}$ may cause transgression under Australian law.

There may be a case that the nature of this Aboriginality could be a mitigatory factor for diminished moral culpability and criminal responsibility in an objective test for provocation, particularly where the defendant has a history of petrol sniffing or a disability from the effects of Foetal Alcohol Spectrum Disorder.

The case prosecuted in this paper in respect of consideration of the 'reasonable person' in heterogeneous Australian society and the Australian Aboriginal context may also serve well the characteristics of minorities in other world societies.

This proposition is an early attempt for a legal construction of the contemporary Aboriginalised 'reasonable person' and it seeks to invite others to contribute to developing the notion, rather than seeking others to adopt it.

203 Aboriginal Law is Tjukurpa for the Pitjantjatjara People of NW South Australia and Yolngu Lore for the people of Arnhem Land. 


\section{BIBLIOGRAPHY}

\section{Book}

Smith, J. and B. Hogan. Criminal Law. London: Butterworths. 1996

\section{Journal}

Anthony, Thalia, Lorana Bartells and Anthony Hopkins. "Lessons Lost in Sentencing: Welding Individualised Justice to Indigenous Justice." Melbourne University Law Review 16 (2015).http://www5.austlii.edu.au/au/journals / MelbULawRw/2015/16.html

Applegarth, P D T. "Lord Aitkin: Principle and Progress". The Australian Law Journal 90 No. 10 (2016) http: / / sites.thomsonreuters.com.au/journals/files / 2016/10/ ALJ-Vol-90-No-10-Contents-final.pdf

Burke, Alafair S. "Rational Actors, Self Defense and Duress: Making Sense Not Syndromes Out of the Battered Woman". North Carolina Law Review 81 (2002): 211-316.http://scholarlycommons.law.hofstra.edu/faculty_scholarship/ 165

Christie, Sarah. "Provocation-pushing the Reasonable Man Too Far?”, Journal of Criminal Law 64, no. 4 (2000): 409-415, https://doi.org/10.1177/002201830006400410.

Chroust, Anton- Hermann and David L Osborn. "Aristotle's Conception of Justice."Notre Dame Law Review 17, No. 2 (1942): 129-143. http://scholarship. law.nd.edu/ndlr/vol17/iss2/2

Edney, Richard. "The Retreat From Fernando and the Erasure of Indigenous Identity in Sentencing," Indigenous Law Bulletin 6 No.17 (2006): 8. http:/ www.austlii. edu.au/au/journals/IndigLawB/2006/11.html

Gardner, John. "The Mysterious Case of the Reasonable Person." University of Toronto Law Journal 51, (2001): 273-308. https://ssrn.com/abstract=1397115

Israel, Mark. "Ethnic Bias in Jury Selection in Australia and New Zealand." International Journal of the Sociology of Law 26, no. 1 (1998): 35-54. https://doi.org/10.1006/ ijsl.1998.0057

Nourse, Victoria. "After the Reasonable Man: Getting over the Subjectivity/Objectivity Question." New Criminal Law Review: In International and Interdisciplinary Journal 11, no. 1 (2008): 33-50. http://doi.org/10.1525/nclr.2008.11.1.33 
Riley, Trevor. "Aborigines and the Court: The Northern Territory Experience." Northern Territory Law Journal 2, No. 4 (2012): 215-226.http://sites.thomsonreuters. com.au/journals / files / 2012/09 / Nthn-Territory-Law-Jn1-Vol-2-No-4-Sep2012.pdf

"Taking Indigenous Over-Imprisonment Seriously: Time For Concrete Solutions Not More Good Intentions”.Editorial.Criminal Law Journal 39 No.5 (2015). http:/ / sites.thomsonreuters.com.au/journals/files/2015/10/Crim-LJ-Vol-39-No-5Contents.pdf

\section{Legal Document}

Autralian Criminal Code

International Covenant on Civil and Political Rights

United Kingdom Homicide Act 1957

\section{Other Document}

Aboriginal and Torres Strait Islander Social Justice Commissioner Reports.Bringing Them Home Report on Stolen Generations. May 1997

Australian Law Reform Commission Report on Aboriginal Customary Law Report 31.https://www.alrc.gov.au/sites/default/files/pdfs/publications / ALRC31.pdf

Charles, Christopher. The Law of Sentencing Applied to Aboriginal People In South Australia. http:/ / aija.org.au/Ind\%20Courts\%20Conf\%2013/Papers/Charles.pdf.

Doussa J, Von. Launch of the Supreme Court Equal Treatment Benchbook. Speech delivered at Banco Court Supreme Court of Queensland on 15 February 2006. https: / / www.humanrights.gov.au/news / speeches / launch-supreme-courtequal-treatment-benchbook

Martin AC, Wayne. Access to Justice in Multicultural Australia. Judicial Council on Cultural Diversity, Cultural Diversity and Law Conference on 13 March 2015. http://www.supremecourt.wa.gov.au/_files/Speeches_Cultural\%20Diversity\%20and\%20the \%20Law\%20Conference\%20-\%20Access \%20to\%20Justice\%20in\%20Multural\%20Australia\%20by\%20the $\% 20$ Hon $\% 20$ Wayne $\% 20$ Martin\%20AC,\%20Chief\%20Justice\%20of\%20Western\%20Australia.pdf.

Multiculturalism and the Law, Australian Law Reform Commission ALRC 1992 No. 57.http:/ / www.austlii.edu.au/au/other/lawreform/ALRC/1992/57.html\#8>

Norris QC, Stephen. Sentencing Aboriginal Offenders -Not enough 'judicial notice'?. Judicial Conference of Australia Colloquium in Sydney on 13 October 2013. 
Rothman AM, Stephen. The Impact of Bugmy and Munda on Sentencing Aboriginal and Other Offenders. Paper delivered at the NgaraYura Committee Twilight Seminar on 25 February 2014, <http://www.supremecourt.justice.nsw.gov. au / Documents / Publications / Speeches / Pre-2015\%20Speeches / Rothman/ rothman\%2025\%20feb\%202014.pdf>.

Royal Commission Into Aboriginal Deaths in Custody National Report.May 1991. http://www.austlii.edu.au/au/other/IndigLRes/rciadic/\#national

\section{Case Law}

Bugmy v The Queen [2013] HCA 37

Davis Contractors Ltd v Fareham Urban District Council [1956] AC 696.

Donoghue v Stevenson [1932] AC 562

Fernando (1992) 76 A Crim R 50

Hall v. Brooklands Auto-Racing Club (1933) 1 KB 205

Healthcare at Home Limited $v$ The Common Services Agency (Scotland) [2014] $W L R(D) 351$

Houghagen v Charra (1989) 50 SASR 419

Kable v DPP (1995) 38 NSWLR 374

Leech v Peters (1988) 40 A Crim R 350

Lindsay $v$ The Queen [2015] HCA 16

Masciantonio $v$ R [1991] HCA 22

Munda $v$ Western Australia [2013] HCA 38

Neal $v$ The Queen 149 CLR 305 at 326

New South Wales v Hill (No 5)[2013] NSWSC 140

People v Goetz 497 N.E.2d 41 N.Y. 1986

$R v$ Anunga(1976) 11 ALR 412

$R v$ Ceissman(2001) NSWCCA 73

$R v$ Clarke [2013] NSWCCA 260

$R v$ Fernando (1992) 76 Australian Criminal Reports 58 
$R v$ GJ (2005) 16 NTLR 230 at 30

$R v$ Gladue[1999]1 SCR 688

$R v$ Grose (2014) 114 SASR 92

$R$ v Ipeelee[2012] 1 SCR 433

$R v \operatorname{Pitt}(2001)$ NSWCCA 156

$R v$ Hughes; $R v$ Rigney-Brown [2016] SASCFC 126 (2 December2016)

Regina (Director of Public Prosecutions) v Camplin[1978] 2 All ER 168

Reg. v. Hill (1986) 1 SCR 313

Regina $v$ Smith (Morgan James) HL 27 Jul 2000

State v Norman 378 S.E.2d 8, 10 N.C. 1989

Stingle $v$ R [1990] HCA 61

Wong $v$ The Queen [2001] HCA 64

\section{Website Content/Internet}

Australian Institute of Criminology. "Indigenous Justice in Focus, Australian Institute of Criminology 5 May 2015." http://www.aic.gov.au/crime_types/ in_focus/indigenousjustice.html

Dowdell, Andrew. "Supreme Court Chief Justice Chris Kourakis Hits Out At South Australian Indigenous Toll". http://www.adelaidenow.com.au/news/southaustralia/supreme-court-chief-justice-chris-kourakis-hits-out-at-south-australia-indigneous-jail-toll/news-story/7c474944e368a5f7d526c60eb5175dd97

French AC, Robert. "Equal Justice and Cultural Diversity: the General Meets the Particular". http://www.hcourt.gov.au/assets/publications/speeches/ current-justices/frenchcj/frenchcj14mar15.pdf

Moran, Mayo. "Rethinking the Reasonable Person-An Egalitarian Reconstruction of the Objective Standard".http: / www.oxfordscholarship.com/view/10.1093/ acprof:oso/9780199247820.001.0001/acprof-9780199247820

"Summary of R v Gladue by the SCC in the Ipeelee Case".http://www.gladueprinciples. ca/downloads/ipeelee-gladue-summary.pdf 